\title{
Job Demands, Job Resources dan Kemampuan Adaptasi Karir terhadap Niat Mengundurkan Diri
}

\author{
Hendra Kusuma ${ }^{1}$, Siti Zahreni ${ }^{1}$, Hasnida ${ }^{{ }^{*}}$ \\ ${ }^{1}$ Program Studi Magister Psikologi Sains, Universitas Sumatera Utara Medan, Indonesia \\ Jl. DR. Mansyur No.7, Padang Bulan, Medan Baru, Kota Medan, Sumatera Utara 20155, Indonesia \\ email: hasnida@usu.ac.id
}

\begin{abstract}
Artikel Info
ABSTRAK

Received:

13 Januari 2019

Revised:

10 Februari 2019

Accepted:

18 Maret 2019

Penelitian ini bertujuan melihat pengaruh job demands, job resources dan kemampuan adaptasi karier terhadap niat mengundurkan diri asisten kebun kelapa sawit di Indonesia. Karyawan perlu keseimbangan antara job demands (misal kelebihan beban kerja) dan resources, untuk mengurangi tekanan kerja dan niat mengundurkan diri. Resources dapat berasal dari pekerjaan (misal keamanan kerja, dukungan organisasi, peluang pertumbuhan dan kemajuan) dan dari pribadi (misal kemampuan adaptasi karier). Penelitian ini menggunakan structural equation model (SEM) dengan AMOS. Hasil penelitian menunjukkan pengaruh positif job demands, dan pengaruh negatif job resources serta kemampuan adaptasi karir terhadap niat mengundurkan diri. Penelitian juga menyimpulkan adanya peran mediasi kemampuan adaptasi karier pada hubungan job demands dan job resources terhadap niat mengundurkan diri.
\end{abstract}

Kata Kunci: Asisten kebun kelapa sawit, job demands-resources, kemampuan adaptasi karir, niat mengundurkan diri

\section{Job Demands, Job Resources and Career Adaptability on Turnover Intention}

\section{ABSTRACT}

This study aims to see the effect of job demands, job resources and career adaptability on turnover intention among palm oil field assistant. Employee needs to balance demands (eg. job overload) and resources, in order to reduce stress and turnover intention. Resources can be divided into job resources (eg. job security, organization support, growth opportunities and advancement) and personal resources (eg. career adaptability). This study used structural equation modeling (SEM) with AMOS. Result indicates positive influence of job demands and negative influence of both job resources and career adaptability on turnover intention. However, career adaptability also show mediating effect in the relationship between job demands and job resources with turnover intention.

Keywords: Career adaptability, job demands-resources, palm oil field assistant, turnover intention.

Cara Sitasi :

Kusuma, H., Siti Zahreni, S., Hasnida. (2019). Job Demands, Job Resources dan Kemampuan Adaptasi Karir terhadap Niat Mengundurkan Diri. Jurnal Ilmiah Manajemen dan Bisnis, 20(1), 1-14. https://doi.org/10.30596/jimb.v20i1.2623. 


\section{PENDAHULUAN}

Perkebunan kelapa sawit dewasa ini merupakan industri yang terus berkembang di Indonesia. Sampai tahun 2017, diperkirakan total luas perkebunan kelapa sawit mencapai 12.307.677 hektar atau meningkat lebih dari 9.000\% dari total luas lahan di tahun 1970 . Dari total luasan lahan tersebut 55,24\% diantaranya dikelola oleh Perkebunan Besar Swasta (PBS) dan mayoritas berada di Pulau Sumatera (7.032.857 hektar) dan Pulau Kalimantan (3.714.292 hektar) (Direktorat Jenderal Perkebunan, 2017). Perkembangan industri ini mendorong peningkatan kebutuhan sumber daya manusia. Sumber daya manusia perkebunan kelapa sawit biasanya dibagi menjadi karyawan langsung (seperti pemanen dan tukang muat) dan karyawan tidak langsung (seperti karyawan administrasi, perawatan dan keamanan). Karyawan-karyawan ini dipimpin oleh staf yang terdiri dari asisten kebun, kepala tata usaha, dan manager kebun. Hasil penelusuran peneliti, mendapati bahwa penelitian terhadap staf perkebunan relatif masih sangat minim dilakukan di Indonesia.

Penelitian ini memfokuskan diri pada asisten kebun/afdeling karena bisa dikatakan bahwa asisten kebun merupakan ujung tombak pengelolaan perkebunan kelapa sawit. Asisten kebun adalah staf operasional yang memimpin satu afdeling dengan luas antara 800 sampai dengan 1.000 hektar. sehariharinya asisten kebun bertanggungjawab terhadap berbagai pekerjaan teknis operasional mulai dari panen, perawatan (gawangan, pupuk dan jalan) dan pencatatan administratif (hasil produksi, penggunaan pupuk dan racun hama, serta absensi karyawan). Selain itu, asisten juga harus mengelola pengaturan pengangkutan buah dari lapangan sampai ke pabrik, serta memastikan buah yang dipanen di hari tersebut dapat langsung sampai di pabrik pada hari itu juga, untuk menghindari penurunan kualitas (Andhini, 2014). Untuk mengerjakan berbagai pekerjaan teknis tersebut, asisten kebun dibantu oleh 120 sampai dengan 150 orang karyawan langsung (Pahan, 2008). Oleh karenanya, selain pemahaman teknis, asisten kebun juga harus mampu untuk mengelola sumber daya manusia (SDM) di areal yang dipimpinnya tersebut. Padahal biasanya asisten kebun merupakan lulusan jurusan pertanian yang lebih fokus pada permasalahan teknis tanaman.

Besarnya tanggungjawab baik dari luasan lahan yang harus dikelola, variasi pekerjaan teknis yang harus dilakukan, hingga pengelolaan sumber daya manusia tampaknya menjadikan tekanan (stress) tersendiri untuk asisten kebun. Oleh karenanya, tidak mengherankan banyak asisten perkebunan yang memilih untuk mengundurkan diri, meski telah diikat dengan kontrak kerja (Andhini, 2014). Penelitian Prihutami dkk. (2015) dan Setyanto dkk. (2013) juga menunjukkan adanya peningkatan angka pengunduran diri pada staf perkebunan (termasuk asisten kebun) di dua perusahaan perkebunan kelapa sawit swasta nasional.

Pengunduran diri yang dilakukan oleh asisten kebun akibat tekanan kerja dapat digolongkan sebagai pengunduran diri suka rela (voluntary turnover). Pengunduran diri secara suka rela adalah pengunduran diri yang dilakukan atas keinginan karyawan sendiri (Price, 2001). Disebut atas keingianan karyawan sendiri, karena perusahaan tentunya berharap karyawannya tidak mengundurkan diri, mengingat besarnya biaya yang telah dikeluarkan dalam proses pe-recruit-an maupun pelatihan, yang diperkirakan merupakan faktor biaya tertinggi kedua setelah pemupukan (Infosawit, 2017). Selain itu, pengunduran diri secara tidak terencana ini juga dapat mempengaruhi strategi kinerja yang telah ditetapkan oleh perusahaan.

Berbagai penelitian menunjukkan bahwa pengunduran diri sukarela dipengaruhi oleh berbagai faktor, salah satunya adalah tekanan kerja (Ongori, 2007; Price, 2001). Perasaan tertekan dapat terjadi ketika ada 
ketidakseimbangan antara job demands dan job resources (Bakker \& Demerouti, 2007). Secara lebih spesifik Jackson \& Rothmann (2005) menjelaskan bahwa perasaan tertekan akan dirasakan seseorang ketika job demands dari pekerjaannya tinggi dan tidak diimbangi oleh job resources yang cukup. Rothmann dkk. (2006) menyebutkan bahwa salah satu contoh job demands adalah beban kerja berlebih (work overload). Sedangkan job resources diantaranya adalah kesempatan untuk berkembang (growth opportunity), dukungan organisasi (organization support), perasaan aman (job security), dan kemajuan (advancement)

Sebagaimana disebutkan sebelumnya, pekerjaan sebagai asisten kebun sangat beragam mulai dari teknis operasional pengelolaan lahan sampai dengan pengelolaan sumber daya manusia. Hal ini menyebabkan asisten kebun memiliki job demands yang tinggi yaitu berupa beban kerja yang besar. Job demands yang tinggi tersebut tidak diimbangi dengan job resources yang memadai. Pra penelitian yang dilakukan Andhini (2014) menunjukkan bahwa asisten kebun tidak mendapatkan job resources, seperti dukungan organisasi dan atasan serta ketersediaan pelatihan, yang memadai. Dalam pra penelitian tersebut, Andhini (2014) mencatat bahwa asisten kebun kerap merasa tidak diarahkan oleh atasan, sehingga mengalami kebingungan mengenai peran, tugas dan tanggungjawabnya. Andhini (2014) juga menemukan hampir $11 \%$ asisten kebun merasa tidak mendapatkan pelatihan yang cukup, pelatihan tidak dilakukan secara reguler, atau dilakukan secara tidak merata pada semua asisten. Asisten-asisten tersebut juga berpendapat bahwa kurangnya pelatihan yang diberikan membuat mereka mengalami rintangan dalam bekerja (Andhini, 2014) dan pada akhirnya kesulitan untuk mencapai target yang ditetapkan oleh perusahaan.

Savickas \& Porfeli (2012) menjelaskan bahwa untuk menghadapi situasi yang sulit dan tidak menyenangkan dalam pekerjaannya, seseorang membutuhkan kemampuan untuk beradaptasi karir (career adaptability). Kemampuan adaptasi karir merupakan contoh dari personal resources yang dapat digunakan secara bersama-sama dengan job resources untuk menghadapi job demands (Tladinyane, 2016). Peran kemampuan adaptasi ini dapat membantu seseorang untuk menghadapi situasi yang tidak mengenakkan di tempat kerja, sehingga menurunkan keinginannya untuk mengundurkan diri (Schaufeli, 2017; Rudolph dkk., 2017; Chan \& Mai, 2015; Price, 2001).

Berangkat dari paparan diatas, penelitian ini dilakukan untuk melihat pengaruh job demands dan job resources terhadap keinginan asisten kebun untuk mengundurkan diri. Penelitian ini juga ingin melihat pengaruh kemampuan adaptasi karir pada asisten kebun terhadap niat mengundurkan diri. Penelitian ini bermaksud untuk menguji Job Demands-Resources (JDR) model, yaitu model hubungan job demands, job resources serta kemampuan adaptasi karir (sebagai contoh dari personal resources) dengan niat mengundurkan diri. Pekerjaan sebagai asisten kebun kelapa sawit sengaja dipilih dalam penelitian ini karena model JDR belum pernah dilakukan pada jenis pekerjaan ini. Selain itu penelitianpenelitian sebelumnya juga tidak secara khusus menempatkan asisten kebun sebagai fokus, penelitian sebelumnya melihat staf kebun dan karyawan secara keseluruhan.

Pengunduran diri karyawan (employee turnover) bisa diartikan sebagai perilaku karyawan meninggalkan perusahaan dan mencari kesempatan untuk bekerja di perusahaan lain (Handoko, 2012). Pengunduran diri mendapat perhatian manajemen karena berimbas pada efektivitas kinerja perusahaan (Price, 2001), menyulitkan manajemen untuk fokus pada penerapan pengembangan sistem (Andhini, 2014), dan menghilangkan praktek terbaik (best practise) (Flinkman, dkk., 2010). Price (2001) membagi pengunduran diri menjadi 
pengunduran diri yang bukan berasal dari keingian karyawan (involuntary turnover) dan pengunduran diri yang berasal dari keinginana karyawan/sukarela (voluntary turnover). Pengunduran diri yang bukan berasal dari keinginan karyawan biasanya berhubungan dengan kebutuhan perusahaan. Contohnya adalah pemutusan hubungan kerja (PHK) karena kebutuhan efisiensi perusahaan atau pemutusan hubungan kerja karena karyawan telah masuk masa pensiun. Hal ini membuat perusahaan sudah dapat mengantisipasi akibat yang ditimbulkan oleh pengunduran diri ini. Sedangkan, pengunduran diri atas inisiatif karyawan sendiri bisa terjadi sewaktu-waktu sehingga dapat mengganggu rencana yang telah disiapkan oleh perusahaan. Untuk mengantisipasi pengunduran diri sukarela ini, perusahaan perlu memiliki indikator yang dapat digunakan untuk memprediksi kemungkinan tersebut. Berbagai penelitian menunjukkan bahwa niat untuk mengundurkan diri dari pekerjaan (turnover intention) merupakan indikator yang paling dapat diandalkan. (Hom dkk., 2017).

Konsep pengunduran diri secara sukarela berawal dari teori March dan Simon mengenai kesetimbangan organisasi (organizational equilibrium theory) (Hom dkk., 2017). Dalam teori tersebut dijelaskan bahwa keputusan untuk mengundurkan diri dipengaruhi oleh persepsi tentang kemudahan untuk berpindah (perceive ease to movement) dan persepsi mengenai keinginan untuk berpindah (perceived desirability to movement) (Weibo dkk., 2010). Niat untuk mengundurkan diri terlihat dari sikap seseorang terhadap perilaku mengundurkan diri tersebut. Niat untuk mengundurkan diri merupakan penghubung antara proses berpikir untuk mengundurkan diri (cognitive process) dengan tindakan mengundurkan diri (behavioral action) (Steel \& Ovalle, 1984).

Bothma \& Roodt (2013) dengan mengacu pada teori perilaku yang direncanakan (planned behavior theory)
Fishbein dan Azjen dan teori pengunduran diri Mobley, menjelaskan bahwa terdapat unsur perasaan (affection), pemikiran (cognition) dan konasi pada perilaku pengunduran diri seseorang dari pekerjaannya. Unsur perasaan tampak ketika karyawan melakukan evaluasi dan menyatakan nyaman atau tidak nyaman dengan pekerjaannya saat ini. Aspek pemikiran, tampak dari proses pencarian alternatif dan membandingkan masingmasing alternatif pekerjaan. Sedangkan niat mengundurkan diri merupakan aspek konasi dari perilaku mengundurkan diri yang menjadi indikator bahwa perilaku pengunduran diri akan terjadi (Bothma \& Roodt, 2013).

Salah satu faktor penyebab munculnya niat mengundurkan diri adalah tekanan (stress) kerja (Price, 2001). Tekanan kerja terjadi ketika ada ketidakseimbangan antara job demands dan job resources, khususnya ketika job demands tinggi dan tidak diimbangi oleh job resources yang cukup (Jackson \& Rothmann, 2005). Job demands merupakan aspek fisik, psikologis, sosial dan organisasi dari suatu pekerjaan yang mengharuskan usaha terus-menerus (Demerouti dkk., 2001). Tekanan kerja terjadi ketika untuk memenuhi job demands dibutuhkan usaha yang sangat besar dan karyawan tidak memiliki kemampuan yang cukup untuk segera pulih dari kelelahan yang timbul dari usahanya tersebut (Bakker \& Demerouti, 2007). Rothmann dkk., (2006) menjelaskan bahwa salah satu contoh dari job demands adalah beban kerja berlebih (work overload). Beban kerja berlebih mengacu pada jumlah pekerjaan yang dilakukan, tuntutan emosional dan tuntutan mental dari pekerjaan tersebut. Karyawan akan kehabisan energi ketika terus berusaha untuk memenuhi beban kerja yang berlebih tersebut, sehingga merasa tidak nyaman dan meningkatkan niat untuk mengundurkan diri.

Untuk menghadapi job demands, karyawan membutuhkan job resources. Job 


\section{Published April 2019 \\ JURNAL ILMIAH MANAJEMEN DAN BISNIS \\ ISSN 1693-7619 (print) | ISSN 2580-4170 (online), http://jurnal.umsu.ac.id/index.php/mbisnis}

resources mengacu pada kondisi fisik, psikologis, sosial dan biaya psikologis dari suatu pekerjaan yang berfungsi untuk mencapai tujuan dari pekerjaan yang dilakukan (Demerouti dkk., 2001). Job resources juga berfungsi untuk menstimulasi perkembangan dan proses belajar. Berkebalikan dengan job demands yang menghabiskan energi, job resources justru akan meningkatkan energi seseorang, sehingga membuatnya merasa terikat dengan pekerjaan yang dilakukannya (Schaufeli, 2017). Dalam kondisi yang menekan, seseorang yang memiliki sumber daya yang tinggi akan lebih mampu untuk mengatasinya tuntutan pekerjaan yang dihadapinya (Xanhopoulou dkk., 2007). Hal ini akan mengurangi kecenderungan munculnya niat untuk mengundukan diri.

Penelitian Rothmann dkk. (2006) menyimpulkan empat contoh dari job resources yaitu kesempatan pengembangan (growth opportunity), dukungan organisasi (organizational support), kemajuan (advancement), dan keamanan dalam bekerja (job security). Kesempatan pengembangan mengacu pada keberagaman variasi pekerjaan, ketersediaan kesempatan untuk belajar dan kemandirian dalam bekerja. Dukungan organisasi mengacu pada hubungan dengan atasan dan dukungan dari rekan kerja, ketersediaan informasi, komunikasi di dalam organisasi, partisipasi, serta kesempatan membuat koneksi di dalam organisasi. Kemajuan berarti bergerak maju dalam pekerjaan termasuk dalam hal penggajian (renumerasi), kesempatan karir dan kesempatan mendapatkan pelatihan. Sedangkan, keamanan dalam bekerja mengacu pada perasaan aman yang dirasakan kondisi pekerjaan saat ini dan di masa yang akan datang.

Taris \& Schaufeli (2016) menjelaskan bahwa terdapat instrumen lain yang mirip dengan job resources yang dapat digunakan untuk untuk menghadapi job demands. Instrument tersebut adalah personal resources, yaitu evaluasi pribadi yang positif yang berhubungan dengan keuletan dan perasaan mampu untuk mengkontrol pengaruh lingkungan (Xanthopoulou dkk., 2007). Tladinyane, (2016) menjelaskan bahwa salah satu contoh personal resources adalah kemampuan adaptasi karir (career adaptability). Kemampuan adaptasi karir diartikan sebagai gabungan perilaku, kompetensi dan sikap yang terlibat dalam usaha seseorang untuk mencocokkan diri dengan pekerjaan yang dianggapnya sesuai (Maggiori dkk., 2015). Kemampuan adaptasi karir membuat seseorang mampu menghadapi kondisi yang tidak lazim, kompleks, tidak menyenangkan, perubahan peran, dan trauma dalam bekerja (Savickas \& Porfeli, 2012). Seseorang dengan kemampuan adaptasi karir yang baik akan mampu menghadapi tuntutan kerja dan mengembangkan keterikatan dengan pekerjaannya (Tladinyane, 2016) dan akan berupaya mengimplementasikan konsep diri yang dimilikinya pada tuntutan peran yang muncul pada masa transisi dari masa sekolah ke dunia kerja, dari satu perusahaan ke perusahaan lain maupun dari suatu profesi ke profesi yang lain (Potgieter, 2013). Tujuannya adalah menyesuaikan diri antara harapan yang dimiliki dengan kesempatan yang disediakan oleh lingkungan yang ditunjukkan dengan kesuksesan, perasaan nyaman dan perkembangan (Savickas \& Porfeli, 2012). Seseorang dengan kemampuan adaptasi karir juga akan secara efektif meningkatkan kesadaran dengan cara mencari informasi-informasi yang dapat digunakan untuk mengambil keputusan dan meningkatkan komitmen. Peningkatan kesadaran tersebut akan membuatnya mampu untuk mengatur peran yang dijalani secara efektif dan mempersiapkan diri terhadap kemungkinan terjadinya kehilangan keterikatan (disengagement) terhadap perannya saat ini (Savickas \& Porfeli, 2012).

Berdasarkan penelitian sebelumnya maka hipotesa yang diajukan peneliti adalah: Hipotesa 1a : ada pengaruh job demands 


\section{Published April 2019 \\ JURNAL ILMIAH MANAJEMEN DAN BISNIS \\ ISSN 1693-7619 (print) | ISSN 2580-4170 (online), http://jurnal.umsu.ac.id/index.php/mbisnis}

terhadap kemampuan adaptasi karir pada asisten kebun. Hipotesa 1b: ada pengaruh job resources terhadap kemampuan adaptasi karir pada asisten kebun. Hipotesa $2 \mathrm{a}$ : ada pengaruh job demands terhadap niat asisten kebun untuk mengundurkan diri. Hipotesa $2 b$ : ada pengaruh job resources terhadap niat asisten kebun untuk mengundurkan diri. Hipotesa 3 : ada pengaruh kemampuan adaptasi karir dengan niat asisten kebun untuk mengundurkan diri. Hipotesa 4 : kemampuan adaptasi karir akan memediasi hubungan antara karakteristik pekerjaan dengan niat mengundurkan diri.

\section{METODE}

Pada penelitian ini sampel dipilih berdasarkan pada ciri atau sifat tertentu yang memiliki sangkut paut yang erat dengan ciri atau sifat populasi yang sudah diketahui sebelumnya (Bryman, 2016). Sifat atau ciri ditetapkan peneliti pada penelitian ini adalah asisten kebun kelapa sawit yang bekerja di perusahaan kelapa sawit swata di Sumatera maupun Kalimantan dengan masa kerja minimal satu tahun. Peneliti tidak dapat memperoleh informasi maupun data valid mengenai total jumlah asisten kebun di Sumatera dan Kalimantan. Oleh karenanya, penelitian tetap dilanjutkan dengan mengasumsikan bahwa populasi tidak diketahui. Pengambilan data penelitian dilakukan secara daring (on-line) sepanjang bulan Oktober 2018. Pada akhir bulan Oktober jumlah kuesioner yang masuk adalah 300 buah data. Dari keseluruhan data tersebut 68 responden tidak memenuhi kriteria yang ditentukan. Selain itu, dari uji awal ditemukan 27 data yang tergolong outlier, sehingga total data akhir yang digunakan adalah 205 buah data. Data yang diperoleh kemudian dianalisa dengan menggunakan model persamaan struktural (structural equation model/SEM). Koefisien cronbach alpha dihitung dengan menggunakan persamaan Mosier (Azwar, 2016), untuk menguji realibilitas masingmasing alat ukur yang digunakan.
Job demands dalam penelitian ini diwakili oleh kelebihan beban kerja yang diartikan sebagai persepsi asisten kebun terhadap jumlah pekerjaan yang dilakukan, tuntutan emosional dan tuntutan mental dari pekerjaannya. Job resources diwakili oleh keamanan kerja, kesempatan pengembangan, dukungan organisasi, dan kemajuan. Keamanan kerja adalah persepsi asisten kebun mengenai kejelasan pekerjaannya saat ini dan di masa akan datang. Kesempatan pengembangan adalah persepsi asisten kebun terhadap variasi tugas di dalam pekerjaan, ketersediaan kesempatan untuk belajar dan kemandirian dalam bekerja. Dukungan organisasi adalah persepsi asisten kebun terhadap pada pola hubungan dengan atasan maupun rekan seprofesi, alur informasi dan komunikasi didalam organisasi, serta kejelasan peran dan pelibatan dalam pengambilan keputusan. Sedangkan kemajuan adalah persepsi asisten kebun pada kemungkinan untuk maju dan berkembang dalam pekerjaannya saat ini, baik dari segi penggajian, kesempatan karir maupun kesempatan mendapatkan pelatihan. Persepsi terhadap job demands dan job resources ini diukur dengan menggunakan 42 item pada job demand-resources scale (JDRS) yang dikembangkan oleh Jackson \& Rothmann (2005). Item pada skala tersebut misalnya adalah Apakah Anda memiliki terlalu banyak pekerjaan yang harus dilakukan?" untuk tuntutan kerja, dan "Apakah Anda dapat mengandalkan atasan Anda ketika mengalami kesulitan?" untuk sumber daya.

Kemampuan adaptasi karir didefinisikan sebagai perilaku, kompetensi dan sikap yang terlibat dalam usaha asisten kebun untuk mencocokkan diri dengan pekerjaan yang telah dipilihnya yang tampak dari perhatian, kontrol, keingintahuan, kepercayaan diri dan kerjasama. Perhatian merupakan kesadaran dan persiapan yang dilakukan asisten kebun untuk karirnya ke depan. Kontrol diartikan sebagai kedisiplinan asisten kebun yang ditunjukkan dengan 
tanggungjawab pribadi untuk menyiapkan diri terhadap perubahan situasi di masa akan datang. Keingintahuan menunjukkan kemampuan asisten kebun untuk mengekplorasi dan mencari informasi mengenai peluang karir yang dipilihnya. Kepercayaan diri merupakan keyakinan asisten kebun untuk melakukan sesuatu yang penting guna memecahkan masalah/rintangan dalam bekerja. Sedangkan kerjasama merupakan kemampuan asisten kebun untuk bekerja bersama orang lain dengan cara berkompromi dan memberikan kontribusi. Kemampuan adaptasi karir ini diukur dengan menggunakan 35 aitem career adapt-ability scale (CAAS+C) yang dikembangkan oleh Savickas \& Porfeli (2017). Salah satu item pada skala tersebut misalnya adalah "Memikirkan seperti apa masa depan karir saya."

Terakhir, keinginan mengundurkan diri diartikan sebagai keputusan mental (konasi) yang dilakukan oleh asisten kebun kelapa sawit untuk meninggalkan pekerjaannya dalam sembilan bulan kedepan. Variabel ini diukur dengan menggunakan turnover intention scale (TIS-6) yang dikembangkan oleh Bothma \& Roodt (2013). Salah satu item dalam skala tersebut adalah Seberapa sering Anda berpikir untuk meninggalkan pekerjaan Anda?.

Ketiga skala tersebut diadaptasi dari versi aslinya dalam bahasa Inggris. Proses adaptasi dilakukan dengan mengikuti kaidahkaidah standar International Test Commission (International Test Commission, 2017). Kaidah-kaidah yang diikuti diantaranya adalah proses perijinan penggunaan alat ukur kepada pengembang alat ukur, proses alih bahasa dengan menggunakan lembaga penerjemah terakreditasi, proses pemeriksaan hasil alih bahasa untuk memastikan kesesuaian makna dan pengalihbahasaan kembali ke bahasa Inggris (back translation). Peneliti juga meminta pengembang alat ukut untuk melakukan perbandingan antara skala asli dan hasil alih bahasa ulang, selain juga melakukan uji coba kepada lima orang dengan latar belakang pekerjaan yang berbeda termasuk diantaranya adalah dua orang asisten kebun.

Uji realibilitas alat ukur dilakukan dengan menghitung nilai skor komposit masing-masing alat ukur dengan menggunakan formula Mosier (Azwar, 2016). Hasil perhitungan menunjukkan seluruh alat ukur memiliki realibilitas yang baik yaitu berada diatas 0,70. Nilai Skor komposit masing-masing alat ukur adalah JDRS $(0,94)$, CAAS+C $(0,96)$ dan TIS $6 \quad(0,78)$. Uji validitas dengan menggunakan metode confirmatory factor analysis (CFA) menunjukkan validitas keseluruhan alat tes cukup baik dengan loading factor bergerak dari 0,65 sampai dengan 0,81 .

\section{HASIL DAN PEMBAHASAN}

Data yang terkumpul dianalisa dengan menggunakan structural equation model (SEM). Analisa dilakukan dengan menggunakan program komputer AMOS. Model yang diajukan untuk penelitian ini ditunjukkan dengan gambar 1

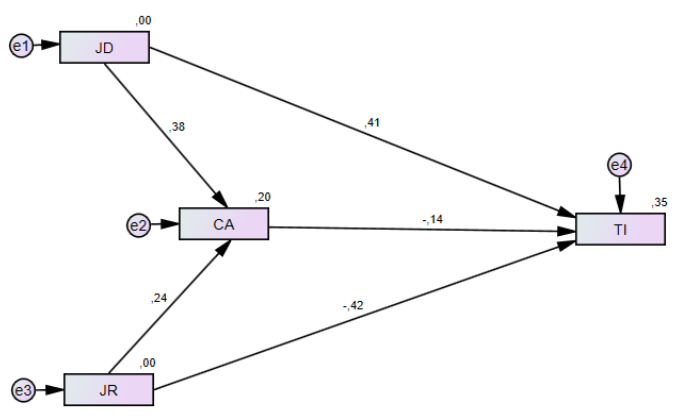

Gambar 1. Model pengukuran

Setelah menentukan model, dilakukan uji asumsi terhadap model. Ghozali (2016) menjelaskan ada beberapa uji asumsi yang perlu dilakukan, yaitu uji kecukupan sampel (sampel size), uji normalitas, dan uji multikolienaritas. Santoso (2011) menjelaskan sampel yang dibutuhkan dalam SEM minimal adalah 15 kali parameter yang diuji. Dalam penelitian ini parameter yang 


\section{Published April 2019 \\ JURNAL ILMIAH MANAJEMEN DAN BISNIS \\ ISSN 1693-7619 (print) | ISSN 2580-4170 (online), http://jurnal.umsu.ac.id/index.php/mbisnis}

digunakan adalah empat parameter, sehingga minimal sampel dibutuhkan adalah $15 \times 4$ parameter $=60$ baris data. Penelitian ini menggunakan 205 responden (baris data) sehingga dapat dinyatakan bahwa sampel pada penelitian ini mencukupi.

Uji normalitas dilakukan dengan melihat critical ratio (cr) skewness value yang ditampilkan oleh AMOS 22. Data disebut normal jika nilai critical ratio (cr) berada pada ambang batas \pm 2.58 pada taraf signifikansi 0.01 (Ghozali, 2016). Hasil uji pada penelitian ini menunjukkan normalitas pada semua variabel, yaitu job demands $(\mathrm{cr}=$ $0,640)$, job resources ( $\mathrm{cr}=-2,185)$, kemampuan adaptasi karir $(\mathrm{cr}=-2,373)$ dan niat mengundurkan diri $(\mathrm{cr}=0,068)$. Secara multivariat normalitas data juga tampak dari nilai $\mathrm{cr}=-1,221$. Selain itu dari uji multikolinieritas juga menunjukkan bahwa tidak terjadi korelasi antar variabel penelitian (nilai determinan matrik kovarian besar = 7.476.158,092). Setelah itu dilakukan uji model dengan melihat kriteria goodness of fit. Hasil hitung menunjukkan goodness of fit yang baik sebagaimana tampak pada tabel 1 .

Tabel 1. Hasil Uji Goodness of Fit Model Penelitian

\begin{tabular}{cccc}
\hline Goodness of Fit Indeks & Cut off Value & Hasil & Evaluasi Model \\
\hline Chi-Square $(\mathrm{df}=1)$ & Diharapkan Kecil & 0,664 & Baik \\
CMIN/DF & $<2.00$ & 0,664 & Baik \\
Sig. Probability & $>0.05$ & 0,415 & Baik \\
GFI & $>0.90$ & 0,998 & Baik \\
AGFI & $>0.90$ & 0,984 & Baik \\
TLI & $>0.90$ & 1,016 & Sangat baik \\
CFI & $>0.95$ & 1,000 & Sangat baik \\
RMSEA & $<0.08$ & 0,000 & Baik \\
\hline
\end{tabular}

Dikarenakan model sudah fit maka selanjutnya dilakukan uji hipotesis. Hipotesa 1a terbukti bahwa ada pengaruh job demands terhadap kemampuan adaptasi karir. Job demands berpengaruh positif dengan koefisien terstandar ( $\beta$ ) 0,376 signifikan pada $p$ value 0,000 . Begitu juga dengan hipotesa $1 \mathrm{~b}$ terbukti bahwa ada pengaruh job resources terhadap kemampuan adaptasi karir. Job resources berpengaruh positif dengan koefisien terstandar ( $\beta$ ) 0,238 signifikan pada $p$ value 0,000 . Hal ini menunjukkan bahwa peningkatan baik job demands maupun job resources akan turut meningkatkan kemampuan adaptasi karir asisten kebun. Selain itu, nilai squared multiple correlation menunjukkan bahwa variabel kemampuan adaptasi karir dapat dijelaskan oleh variabel job demands dan job resources sebesar $19,8 \%$, sedangkan $80,2 \%$ adalah variabel lainnya yang tidak diamati dalam penetilian ini.
Hipotesa 2a terbukti bahwa ada pengaruh job demands terhadap niat mengundurkan diri. Job demands berpengaruh positif dengan koefisien terstandar $(\beta)$ 0,410 signifikan pada $p$ value 0,000 . Hal ini menunjukkan bahwa peningkatan job demands akan turut meningkatkan niat mengundurkan diri pada asisten kebun. Sedangkan hipotesa $2 b$ terbukti bahwa ada pengaruh job resources terhadap niat mengundurkan diri. Job resources berpengaruh negatif dengan koefisien terstandar $(\beta)-0,421$ signifikan pada $p$ value 0,000 . Hal ini menunjukkan bahwa peningkatan job resources akan menurunkan niat mengundurkan diri pada asisten kebun. Pada hipotesa 3, hasil pengujian juga membuktikan ada pengaruh kemampuan adaptasi karir terhadap niat mengundurkan diri. Kemampuan adaptasi karir berpengaruh negatif dengan koefisien terstandar $(\beta)-0,139$ signifikan pada $p$ value 0,028 . Hal ini menunjukkan bahwa peningkatan 


\section{Published April 2019 \\ JURNAL ILMIAH MANAJEMEN DAN BISNIS \\ ISSN 1693-7619 (print) | ISSN 2580-4170 (online), http://jurnal.umsu.ac.id/index.php/mbisnis}

kemampuan adaptasi karir akan menurunkan niat mengundurkan diri pada asisten kebun. Jika dilihat dari nilai squared multiple correlation, variabel niat mengundurkan diri dapat dijelaskan oleh variabel job demands, job resources, dan kemampuan adaptasi karir sebesar $34,9 \%$, sedangkan $65,1 \%$ adalah variabel lainnya yang tidak diamati dalam penetilian ini.

Untuk menguji hipotesa 4, digunakan pengujian dari Baron dan Kenny (1986). Pada model tersebut dijelaskan bahwa ada tiga persyaratan untuk menguji efek mediasi. (1) Adanya korelasi yang signifikan antara variabel bebas $(\mathrm{X})$ dengan variabel mediator. Pada penelitian ini, signifikansi hubungan tersebut terbukti pada hipotesa 1. (2) Terdapat hubungan yang signifikan antara variabel mediator (M) dengan variabel terikat (Y), yang tampak dari pembuktian hipotesa 3. Dan (3) dalam kondisi hubungan antara variabel bebas (X) dengan variabel mediator (M) dan hubungan antara variabel mediator (M) dengan variabel terikat (Y) dikontrol, hubungan antara variabel bebas (X) dan variabel terikat (Y) tidak lagi signifikan.
Pengaruh mediasi total terjadi ketika besar hubungan antara variabel bebas dan variabel terikat ini adalah nol, sedangkan semakin besar hubungannya menunjukkan semakin kecil efek mediasi diberikan oleh variabel mediator. Pada penelitian ini, hasil perhitungan menunjukkan pengaruh tidak langsung (indirect effect) antara job demands terhadap niat mengundurkan diri mengecil dari pengaruh langsungnya (direct effect) yaitu dari $-0,410$ menjadi $-0,052$. Begitu juga pengaruh langsung tidak langsung (indirect effect) job resources terhadap niat mengundurkan diri mengecil dari pengaruh langsungnya (direct effect) yaitu dari 0,421 menjadi 0,033. Selain itu uji sobel menunjukkan bahwa hubungan tersebut tidak signifikan $\left(\mathrm{t}_{\text {hitung }}\right.$ job demands $=5,199<\mathrm{t}$ tabel $=12,706 ; \mathrm{t}_{\text {hitung }}$ job resources $=4,447<\mathrm{t}$ tabel $=12,706)$. Oleh karena itu, penelitian ini menyimpulkan bahwa hipotesa 4 terbukti yaitu bahwa kemampuan adaptasi karir memediasi hubungan antara job demands dan job resources terhadap niat mengundurkan diri.

Tabel 2. Korelasi antar Variabel

\begin{tabular}{lccccccccc}
\hline & \multicolumn{3}{c}{ Job Demand } & \multicolumn{3}{c}{ Job Resources } & \multicolumn{3}{c}{ Career adaptability } \\
\cline { 2 - 9 } & Direct & Indirect & Total & Direct & Indirect & Total & Direct & Indirect & Total \\
\hline $\begin{array}{l}\text { Career } \\
\text { adaptability }\end{array}$ & 0,376 & 0,000 & 0,376 & 0,238 & 0,000 & 0,238 & 0,000 & 0,000 & 0,000 \\
$\begin{array}{l}\text { Turnover } \\
\text { intention }\end{array}$ & 0,410 & $-0,052$ & 0,358 & $-0,421$ & $-0,033$ & $-0,454$ & $-0,139$ & 0,000 & $-0,139$ \\
\hline
\end{tabular}

Keterangan : efek tidak langsung job demands dan job resources terhadap niat mengundurkan diri tidak signifikan

\section{Pembahasan}

Pra penelitian Andhini (2014) menunjukkan pandangan asisten kebun terhadap kondisi pekerjaannya menjadi pemicu niat untuk mengundurkan diri. Kondisi pekerjaan pada penelitian ini diletakkan pada kerangka model JDR, yang membagi kondisi pekerjaan menjadi job demands dan job resources. Berangkat dari pra penelitian tersebut, pada penelitian ini job demands yang digunakan adalah kelebihan beban kerja, sedangkan job resources yang digunakan adalah dukungan organisasi, kesempatan pengembangan, keamanan kerja dan kemajuan. Peneliti kemudian menambahkan kemampuan adaptasi karir sebagai variabel yang berasal dari dalam diri asisten kebun sendiri. Jadi, tujuan utama penelitian ini adalah membuktikan pengaruh job demands, job resources dan kemampuan adaptasi karir terhadap niat mengundurkan diri. 


\section{Published April 2019 \\ JURNAL ILMIAH MANAJEMEN DAN BISNIS \\ ISSN 1693-7619 (print) | ISSN 2580-4170 (online), http://jurnal.umsu.ac.id/index.php/mbisnis}

Hasil penelitian ini menunjukkan bahwa job demands memiliki pengaruh positif signifikan terhadap kemampuan adaptasi karir dan niat mengundurkan diri. Asisten kebun yang merasakan job demands yang tinggi dalam bentuk kelebihan beban kerja, ternyata justru akan berusaha untuk meningkatkan kemampuannya untuk beradaptasi dengan kondisi pekerjaan (karir) yang telah dipilihnya tersebut. Temuan ini sejalan dengan konsep bahwa adanya beban kerja yang berlebih membuat seseorang akan belajar untuk menghadapinya secara efektif (Houkes dkk., 2003). kemampuan adaptasi karir juga disebut sebagai kemampuan seseorang untuk menghadapi tugas-tugas yang berhubungan dengan karir yang dijalaninya (Savickas \& Porfeli, 2012) dan merupakan reaksi yang timbul dari diri seseorang ketika berada dalam situasi yang menekan (Akkermans dkk., 2018). Pada asisten kebun, tekanan tersebut berupa kelebihan beban kerja terjadi karena luasnya cakupan pekerjaan yang harus dilakukan. Untuk mampu menghadapi situasi tersebut ia harus mencari cara yang paling efektif dan tidak beresiko baik terhadap karirnya maupun secara kesehatan fisik maupun mentalnya. Namun, jika kondisi tersebut terus berulang, maka energi yang dimiliki untuk mengantisipasi akan terus terkuras sehingga memunculkan niat untuk mengundurkan diri (Demerouti dkk., 2001). Hasil penelitian ini sejalan dengan berbagai penelitian yang telah dilakukan sebelumnya pada karyawan di perusahaan telekomunikasi (Bon \& Shire, 2017), pekerja pada sektor kesehatan (Xiaoming dkk., 2014) maupun pekerja manufaktur seperti pada pabrik tekstil (Qureshi dkk., 2012).

Hasil penelitian juga menunjukkan bahwa job resources memiliki pengaruh positif signifikan terhadap kemampuan adaptasi karir dan pengaruh yang negatif signifikan terhadap niat mengundurkan diri. Asisten kebun yang merasakan job resources yang tinggi misalnya dalam bentuk dukungan dari organisasi juga akan meningkat kemampuan adaptasi karirnya. Dukungan dari organisasi seperti adanya arahan yang jelas dari atasan, target kerja dan kejelasan deskripsi kerja memberikan tujuan yang jelas yang harus dicapai dan cara yang dapat digunakan untuk menuju tujuan tersebut sekaligus juga memberikan kejelasan koridor cara kerja yang boleh dan tidak boleh dilakukan. Hal ini membantu asisten kebun untuk memenuhi keingintahuannya mengenai apa yang akan dihadapinya dan apa yang harus dilakukan sehingga ia dapat mempersiapkan diri. Kondisi ini tidak hanya terjadi pada asisten kebun yang baru bekerja, karena asisten kebun yang sudah bekerja tetap harus mempersiapkan diri untuk menghadapi berbagai perubahan seperti target kerja yang harus dicapai. Temuan ini sejalan dengan hasil penelitian Han \& Rojewski (2015) yang menjelaskan bahwa keberadaan job resources akan membantu meningkatkan kesiapan dalam menghadapi pekerjaan saat ini maupun di masa depan. Selain itu, job resources juga dipandang dapat meningkatkan kemauan karyawan untuk mencurahkan seluruh kemampuan yang dimilikinya untuk menyelesaikan tugas-tugasnya (Taris \& Schaufeli, 2016). Oleh karenanya, asisten kebun yang bersedia mencurahkan seluruh kemampuannya, tentunya adalah asisten kebun yang memiliki komitment pada pekerjaan atau perusahaannya sehingga dapat dikatakan memiliki niat mengundurkan diri yang rendah. Hasil ini sekaligus juga mengkonfirmasi hasil penelitian sebelumnya misalnya yang dilakukan pada pekerja sosial (Kalidass \& Bahron, 2015), karyawan hotel (Maertz dkk., 2007), maupun karyawan perusahaan milik negara (Samuel \& Chipunza, 2009).

Kemampuan adaptasi karir (sebagai contoh dari personal resources) memiliki peran yang kurang lebuh sama dengan job resources dalam hubungannya dengan niat mengundurkan diri (Taris \& Schaufeli, 2016). Hal ini juga tampak dari hasil penelitian ini 
yang menunjukkan bahwa baik job resources maupun kemampuan adaptasi karir memiliki pengaruh yang negatif signifikan terhadap niat mengundurkan diri. Temuan ini juga mengkonfirmasi temuan penelitian terdahulu yang menunjukkan korelasi negatif antara kemampuan adaptasi karir dengan niat mengundurkan diri (Kim \& Hyun, 2017; Guan dkk., 2015).

Selain itu, kemampuan adaptasi karir juga mediasi hubungan antara job demands dan job resources terhadap niat mengundurkan diri. Sebagaimana dipaparkan sebelumnya, asisten kebun yang menghadapi beban kerja berlebih akan mengembangkan cara untuk menghadapi beban kerja tersebut. Adaptasi dilakukan dengan merubah cara kerja atau mencari alat bantu. Keberhasilan adaptasi akan menurunkan tekanan akibat beban kerja tersebut sehingga meningkatkan kepercayaan diri bahwa ia mampu mengerjakan target yang diberikan dan meningktkan keyakinan akan berhasil dalam karirnya. Keyakinan tersebut akan menurunkan niatnya untuk mengundurkan diri. Hal ini sejalan dengan penelitian yang sebelumnya telah dilakukan yang menunjukkan bahwa optimisme akan keberhasilan karir kedepan dan keyakinan diri untuk dapat menyelesaikan tugas memediasi hubungan antara job demands dengan niat mengundurkan diri (Xanthopoulou dkk., 2007).

\section{SIMPULAN}

Hasil analisa terhadap penelitian ini menunjukkan bahwa job demands dan job resources sebagai kondisi pekerjaan di perkebunan kelapa sawit memberikan pengaruh yang signifikan pada niat mengundurkan diri asisten kebun. Job demands memberikan pengaruh yang positif signifikan, sebaliknya job resources memberikan pengaruh negatif signifikan. Begitu juga dengan kemampuan adaptasi karier yang memberikan pengaruh negatif signifikan terhadap niat mengundurkan diri.
Kemampuan adaptasi karir juga memberikan efek mediasi dalam hubungan antara job demands dan job resources dan niat mengundurkan diri. Peneliti menyarankan perusahaan perkebunan kelapa sawit untuk mengelola job demands dan job resources. Kebutuhan untuk meningkatkan keuntungan terkadang digunakan untuk melakukan efisiensi sehingga meningkatkan beban kerja karyawan. Analisa beban kerja dapat dilakukan untuk memastikan asisten kebun benar-benar optimal dalam bekerja, tanpa memberikan beban kerja berlebih. Selain itu, untuk menurunkan niat mengundurkan diri perusahaan juga perlu meningkatkan job resources. Hal ini dapat dilakukan dengan membuat rencana pengembangan yang transparan sehingga asisten kebun merasakan adanya kesempatan berkarir dan meningkatkan kemampuan adaptasi karir mereka. Ketersediaan kesempatan karir juga dapat meningkatkan rasa aman asisten kebun terhadap pekerjaannya di masa depan. Manajemen perusahaan perkebunan khususnya yang berada di operasional juga perlu berubah. Sebagaimana dijelaskan oleh Pahan (2008) pola kepemimpinan di perkebunan kebanyakan adalah pola kepemimpinan yang melakukan kontrol dengan hukuman. Gaya kepemimpinan ini membuat tidak ada arahan yang memadai pada bawahannya. Manajemen operasional perlu mengubah pola kepemimpinan ini menjadi pola kepemimpinan yang lebih memberikan arahan dengan coaching dan mentoring.

\section{REFERENSI}

Akkermans, J., Paradniké, K., Van der Heijden, B. I. J. M., \& De Vos, A. (2018). The best of both worlds: The role of career adaptability and career competencies in students' well-being and performance. Frontiers in Psychology, 9(1678), 1-13. https://doi.org/10.3389/fpsyg.2018.0167 8 


\section{Published April 2019 \\ JURNAL ILMIAH MANAJEMEN DAN BISNIS \\ ISSN 1693-7619 (print) | ISSN 2580-4170 (online), http://jurnal.umsu.ac.id/index.php/mbisnis}

Andhini, D. F. (1032012). (2014). Penyusunan Alat Assessment Penilaian Kinerja pada Jabatan Asisten Divisi di PT. Darmex Agro Propinsi Riau. Tesis. Universitas Kristen Maranatha. Diakses dari

http://repository.maranatha.edu/8397/

Azwar, S. (2016). Dasar-dasar Psikometrika (II). Yogyakarta: Pustaka Pelajar.

Bakker, A. B., \& Demerouti, E. (2007). The Job Demands-Resources model: State of the art. Journal of Managerial Psychology, 22(3), 309-328. https://doi.org/10.1108/0268394071073 3115

Baron, R. M., \& Kenny, D. a. (1986). The moderator-mediator variable distinction in social psychological research: Conceptual, strategic, and statistical considerations. Journal of Personality and Social Psychology, 51(6), 11731182. https://doi.org/10.1037/00223514.51.6.1173

Bon, A. T., \& Shire, A. M. (2017). The impact of job demands on employees , turnover intentions: A study on telecommunication sector. International Journal of Scientific and Research Publications, 7(5), 406-412.

Bothma, C. F. C., \& Roodt, G. (2013). The validation of the turnover intention scale. SA Journal of Human Resource Management, 11(1), 1-12. https://doi.org/10.4102/sajhrm.v11i1.50 7

Bryman, A. (2016). Social research methods (5th ed.). Oxford: Oxford University Press.

Chan, S. H. J., \& Mai, X. (2015). The relation of career adaptability to satisfaction and turnover intentions. Journal of Vocational Behavior, 89, 130-139. https://doi.org/10.1016/j.jvb.2015.05.00 5

Commission, I. T. (2017). The ITC Guidelines for Translating and Adapting Tests (second edition).
Diakses dari www.InTestCom.org

Demerouti, E., Nachreiner, F., Bakker, A. B., \& Schaufeli, W. B. (2001). The job demands-resources model of burnout. Journal of Applied Psychology, 86(3), 499-512. https://doi.org/10.1037/00219010.86.3.499

Direktorat Jenderal Perkebunan. (2017). Statistik Perkebunan Indonesia 2015 $2017 . \quad$ Diakses dari http://ditjenbun.pertanian.go.id

Flinkman, M., Leino-Kilpi, H., \& Salantera, S. (2010). Nurses intention to leave the profession: integrative review. Journal of Advanced Nursing, 66(7), 1422-1434.

https://doi.org/10.1111/j.13652648.2010.05322.x

Ghozali, I. (2016). Desain Penelitian Kuantitatif \& Kualitatif untuk Akuntansi, Bisnis dan Ilmu Sosial Lainnya. Semarang: Yoga Pratama.

Guan, Y., Zhou, W., Ye, L., Jiang, P., \& Zhou, Y. (2015). Perceived organizational career management and career adaptability as predictors of success and turnover intention among Chinese employees. Journal of Vocational Behavior, 88, 230-237. https://doi.org/10.1016/j.jvb.2015.04.00 2

Han, H., \& Rojewski, J. W. (2015). Genderspecific models of work-bound Korean adolescents ' social supports and career adaptability on subsequent job satisfaction. Journal of Career Development, 42(2), 149-164. https://doi.org/10.1177/0894845314545 786

Handoko, T. H. (2012). Manajemen personalia dan sumberdaya manusia (II). Yogyakarta: BPFE.

Hom, P. W., Lee, T. W., Shaw, J. D., \& Hausknecht, J. P. (2017). One hundred years of employee turnover theory and research. Journal of Applied Psychology, Advance on, 1-17. 
https://doi.org/10.1037/ap10000103

Houkes, I., Janssen, P. P. M., De Jonge, J., \& Bakker, A. B. (2003). Specific determinants of intrinsic work motivation, emotional exhaustion and turnover intention: A multisample longitudinal study. Journal of Occupational and Organizational Psychology, 76(4), 427-450. https://doi.org/10.1348/0963179033225 91578

Infosawit. (2017, April). Darurat Pekerja Sawit, Tahun 2030 Butuh 43 Juta Pekerja. Infosawit.Com. Diakses dari https://www.infosawit.com/news/7469/ darurat-pekerja-sawit--tahun-2030butuh-43-juta-pekerja

Jackson, L., \& Rothmann, S. (2005). Workrelated well-being of educators in a district of the North-West Province. Perspectives in Education, 23(3), 107122.

Kalidass, A., \& Bahron, A. (2015). The relationship between perceived supervisor support, perceived organizational support, organizational commitment and employee turnover intention. International Journal of Business Administration, 6(5), 82-89. https://doi.org/10.5430/ijba.v6n5p82

Kim, W., \& Hyun, Y. S. (2017). The impact of personal resources on turnover intention: the mediating effects of work engagement. European Journal of Training and Development. https://doi.org/10.1108/EJTD-05-20170048

Maertz, C. P., Griffeth, R. W., Cambell, N. S., \& Allen, D. G. (2007). The effects of perceived organizational support and perceived supervisor support on employee turnover. Journal Organizational Behavior, 28, 10591075. https://doi.org/10.1002/job

Maggiori, C., Rossier, J., \& Savickas, M. L. (2015). Career adapt-abilities scaleshort form (CAAS-SF): Construction and validation. Journal of Career Assessment, 1-14. https://doi.org/10.1177/1069072714565 856

Ongori, H. (2007). A review of the literature on employee turnover. African Journal of Business Management, 49-54. https://doi.org/10.1108/1463444971019 5471

Pahan, I. (2008). Panduan lengkap kelapa sawit: Management agribisnis dari hulu hingga hilir. Bogor: Penebar Swadaya.

Potgieter, M. (2013). The relationship between career adaptability and employee engagement amongst employees in an insurance company. Tesis. University of South Africa. Diakses dari http://uir.unisa.ac.za/handle/10500/1374 2 .

Price, J. L. (2001). Reflections on the determinants of voluntary turnover. International Journal of Manpower, 22(7), 600-624. https://doi.org/10.1108/EUM000000000 6233

Prihutami, N. D., Hubeis, M., \& Puspitawati, H. (2015). Strategi human capital group department dalam mengembangkan keterikatan karyawan (employee engagement) (studi kasus: unit operasional PT Bumitama Gunajaya Agro). Jurnal Aplikasi Manajemen, 13(4), 634-642.

Qureshi, Jamil, Iftikhar, Arif, Lodhi, Naseem, Z. (2012). Job stress, workload, environment and employees turnover intentions: destiny or choice. Archives Des Sciences, 65(8), 230-241.

Rothmann, S., Mostert, K., \& Strydom, M. (2006). A psychometric evaluation of the Job Demands-Resources Sclae in South Africa. SA Journal of Industrial Psychology, 32(4), 76-86. https://doi.org/10.4102/sajip.v32i4.239.

Rudolph, C. W., Lavigne, K. N., \& Zacher, H. (2017). Career adaptability: A meta- 


\section{Published April 2019 \\ JURNAL ILMIAH MANAJEMEN DAN BISNIS \\ ISSN 1693-7619 (print) | ISSN 2580-4170 (online), http://jurnal.umsu.ac.id/index.php/mbisnis}

analysis of relationships with measures of adaptivity, adapting responses, and adaptation results. Journal of Vocational Behavior, 98, 17-34. https://doi.org/10.1016/j.jvb.2016.09.00 2

Samuel, M., \& Chipunza, C. (2009). Employee retention and turnover: Using motivational variables as a panacea. African Journal of Business Management, 3(8), 410-415. https://doi.org/10.5897/AJBM09.125

Santoso, S. (2011). Structural Equation Modelling (SEM): Konsep dan Aplikasi dengan AMOS 18. Jakarta: PT. Elex Media Komputindo.

Savickas, M. L., \& Porfeli, E. J. (2012). Career adapt-abilities scale: Construction, reliability, and measurement equivalence across 13 countries. Journal of Vocational Behavior, 80(3), 661-673. https://doi.org/10.1016/j.jvb.2012.01.01 1

Savickas, M. L., \& Porfeli, E. J. (2017). Career Adapt-Abilities Scale + Cooperation Scale (CAAS + C). In National Career Development Association Conference (Vol. 80). Orlando.

https://doi.org/10.1016/j.jvb.2012.01.01 1.

Schaufeli, W. B. (2017). Applying the Job Demands-Resources model: A 'how to' guide to measuring and tackling work engagement and burnout. Organizational Dynamics, 46(2), 120132.

https://doi.org/10.1016/j.orgdyn.2017.0 4.008

Setyanto, A., Suharnomo, \& Sugianto. (2013). Analisis pengaruh kepuasan kerja dan iklim organisasi terhadap keinginan keluar (intention to quit) dengan komitmen organisasional sebagai variabel intervening (Pada perusahaan perkebunan kelapa sawit
Teladan Prima Group). Jurnal Studi Manajemen \& Organisasi, 10(1), 7581.

Steel, R., \& Ovalle, N. (1984). A review and meta-analysis of research on the relationship between behavioral intentions and employee turnover, 69(4), 673-686. https://doi.org/ 10.1037/0021-9010.69.4.673.

Taris, T. W., \& Schaufeli, W. B. (2016). The Job Demands-Resources model. In S. Clarke, T. M. Probst, F. Guldenmund, \& J. Passmore (Eds.), The Wiley Blackwell handbook of the psychology of occupational safety and workplace health (pp. 157-180). John Wiley \& Sons, Ltd.

Tladinyane, R. (2016). Career adaptability and employee engagement of adults employed in an insurance company: An exploratory study. SA Journal of Human Resource Management, 14(1), 1-9. https://doi.org/10.4102/sajhrm. v14i1.752

Weibo, Z., Kaur, S., \& Zhi, T. (2010). A critical review of employee turnover model (1938-2009) and development in perspective of performance. African Journal of Business Management, 4(19), 4146-4158.

Xanthopoulou, D., Bakker, A. B., Demerouti, E., \& Schaufeli, W. B. (2007). The role of personal resources in the job demands-resources model. International Journal of Stress Management, 14(2), 121-141. https://doi.org/10.1037/10725245.14.2.121

Xiaoming, Yang \& Ma, B.-J \& Lisa Chang, Chunchih \& Shieh, C.-J. (2014). Effects of workload on burnout and turnover intention of medical staff: A Study. Studies on Ethno-Medicine., 8, 229237. 